\title{
God's servant working for your own good: Notes from modern South Africa on Calvin's commentary on Romans 13:1-7 and the state.
}

\author{
P J Strauss \\ Department of Ecclesiology \\ University of the Orange Free State
}

\begin{abstract}
This article aims at demonstrating that Calvin's grasp of the message of Romans 13 in its reference to the state is highly relevant for the present South Africa. This includes the belief that the authority of rulers is ordained by God, be it that of a just or an unjust government, and that their right to govern should therefore be respected; that government should maintain a public order of justice and peace within which people can serve God in all spheres of life; that state authorities should use the sword and even the death penalty when needed, and not shy away from this God-given responsibility; that a society in which crime threatens to create chaos needs stronger measures of punishment; and that rebellion against the government or disruption of public life should be resorted to only as an ultimate means and when carefully considered as in the general interest.
\end{abstract}

\section{A TOPICAL THEME}

It is easy enough to convince those who are interested both in Calvin and in the weal and woe of our country of the topicality of this theme. Those interested in Calvin know that he was also involved politically and socially and that he sought to formulate some universally valid truths on the basis of his understanding of the Soli Deo Gloria principle ${ }^{1}$ (De Jong 1987:195-197). These truths apply equally in modern-day postapartheid South Africa.

Furthermore, South Africa is traditionally regarded as one of the countries on which Calvin and Calvinism had a marked influence (Kuyper 1959:32; Simpson 1984 4:ix). What is more, some attribute the rise of apartheid largely to the influence of Calvinism (Hexham 1981; Ntoane 1983). For many the replacement of the old apartheid South Africa with the new South Africa in the nineties of this century therefore represents the supplanting of an oppressive Calvinist tradition by freedom (Ntoane 1983:226) and a vague, religiously determined valuation of 'man' as the basis of a 'new' order or 'process of nationbuilding'. 
The dominance of a secularised political democratism, which appeals variously to the numerical majority of the citizens of the state or to the individual, is evident in a number of spheres of contemporary South African life. On the basis of majority, the nation is regarded as normative for 'populations' of non-political life forms, such as economic and educational institutions, sports organisations, and the civil service as providers of expert help to the authorities. This often happens without regard to the nature and function of these structures and therefore of their requirements for association. So we see a ghastly tyranny of numbers premised on the nation (Capraro 1996a: 9) but showing no respect for the nature of non-state life forms beginning to loom up.

Side by side with this there is the paradigm of each citizen having as much individual freedom as possible in all areas. An example of the possible effect of this paradigm is the handling of the high crime rate by the government of the day. This example is directly related to Romans 13:4: 'his power to punish is real'.

A perception is developing in South Africa that this humanistic individualism is sapping the government's will and capacity to act against crime and violence. Murder, robbery, rape and other crimes have escalated seemingly beyond control. In a report recently released by Nedcor, it is calculated that in 1995 crime cost South Africa R31,3 billion, representing $18,02 \%$ of the $1996 / 7$ budget. In contrast to the average of 5,5 for the rest of the world, 45 per 100,000 of the population of this country are murdered. Only 77 people are arrested in connection with every 1,000 crimes and only 1 out of every 8 criminals does not commit further crimes. What heightens the crisis in this regard is the fact that prison sentences are arbitrarily and drastically reduced at departmental level and offenders are speedily put into 'circulation' once more (Die Volksblad 12-06-1996:3). Business confidence in the government sector's ability to combat crime is at such a low ebb that more people currently work for private security firms than for the police (Die Volksblad 13-06-1996:10). The dogmatic refusal on the part of the authorities to restore the death penalty as a possible punishment creates the impression that the life of the murderer is humanistically absolutised, without weighing it juridically against that of the victim and the maintenance of public order, peace and quiet. In addition, those in power use a favourable climate to pay lip-service to the importance of every single person's opinion. The result: the will of the 'people' individually - is law, but ultimately, in actual fact, it is that of the majority as interpreted and managed by the leadership.

In summary, we are concerned here with ideologies rooted in the Enlightenment and even in post-modernism which are taking over in a country where Calvinism was once gladly heard and applied. They are old, familiar ideologies, which Reformed 
Protestantism tried to dispose of in the past with an anti-revolutionary response (cf Groen van Prinsterer $\mathbf{n}$ d). So we are involved in an ongoing trial of strength, which in the present South African context gives rise anew to what Stoker termed a stryd om die ordes (Stoker s a).

The pragmatist may say that such a theme is undesirable in the present climate. For the Bible believer, however, Romans 13:1-7 remains relevant and pertinent. And precisely because John Calvin (1509-1564) was concerned above all to be an exegete and theologian (Douma \& Van der Vegt 1978:2), an investigation into his exposition of this pericope in the light of modern South Africa - a homiletic angle on it - is also pertinent.

\section{CALVIN AND THE LETTER TO THE ROMANS}

In order to put Calvin's comments on Romans 13:1-7 into context, the following should be borne in mind.

From the first 1536 edition of his Institutes - the distilled summary of Calvin's convictions on doctrine and life $^{2}$ expressed in sermons, Bible commentaries, correspondence and other writings - up to and including the final, definitive edition in 1559 , the fundamental principles of the Reformer's thought remained unaltered (cf Beza 1984:76). And precisely because Calvin wished to be a theologian of Scripture, he grounded his views in this work on Scriptural exegesis (Berkhof 1947:iii-iv). Therefore some of his comments on 'civil government' in the final chapter (Book IV, Chapter XX of the 1559 edition) overlap and are directly related to his commentary on Romans 13, as 'composed at Strasburg in the year 1539' (Owen 1947:iii) and published in 1540 (De Groot 1950:8).

In his foreword to this commentary, a work dedicated to Simon Grynaeus, Calvin says that a commentary on the Bible should be characterised by 'lucid brevity'. He wishes consciously to refrain from long-windedness by not referring to critical material on the passage under consideration or repeating what others have said about the text. This would deflect him from his purpose of expounding what had been written (Calvin 1947:xxiii-xxiv). According to Berkhof, this approach results in Calvin surpassing his Reformation contemporaries in his clean grasp of exegetical principles and his rejection of allegory and extravagant typology $(1947: i v)^{3}$. Calvin was '... not so much an expounder of words, as of principles. He carries on an unbroken chain of reasoning throughout, in a brief and clear manner ...' (Owen 1947:vii).

This kind of exegesis by Calvin not only facilitates our investigation of the theme but also helps us to complement some of Calvin's exegetical remarks with views from his other writings. In this way his attitude to matters may be presented in a wider context. 


\section{BROKENNESS NECESSITATES SUCH A SERVANT}

Calvin places Romans 13 in the context of the total life dedicated to God.

He has no doubt that this passage is concerned with the authority of the magistrates or of the authorities at all levels of government. According to Calvin, the focus is not on a comparison between the authority of the higher and lower levels of government, but on the relationship between authority and the subject. Neither is the form of government at issue, but rather the principles that must apply to all governors and all subjects.

For Calvin the de facto sway of a particular authority entails that it was instituted by God. On the basis of verses 1 and 2 he comes to the simple, direct conclusion that the ruling magistrates are to be obeyed because they are ordained by God. In consequence of the brokenness of the Fall, the Lord God providentially called civil authorities for the lawful and just government of the world (1947:477-479). With reference to Romans 13:1, Calvin says in his other works that resistance to these powers is resistance to the ordinance of God (1962:II, 669; 1948:82).

It is as if Calvin wrote this commentary with one eye on the South African situation. For him a de facto government is de iure because his point of departure is the providence of God. This is diametrically opposed, for example, to the unmotivated canvassing of an authority instituted by means of a just and reasonable process of election in the Nederduitse Gereformeerde Kerk's publication Kerk en samelewing (1990: 40). Calvin does not operate with the liberal-humanistic notion of the state originating from a social contract among autonomous citizens who, by a majority vote, elect and mandate, and thus legitimise, the state authority (Strauss 1992:949-950). In contrast to the ideological cliché current in present-day South Africa (cf e g, Van Niekerk 1987: 11ff; Degenaar 1996:9), Calvin does not link legitimacy and credibility to a broad democratic representativeness, but to divine providential ordination.

\section{A SERVANT FOR YOUR OWN GOOD}

Calvin finds the essence of God's intention in instituting state authority in verse 4, supplemented by phrases from verses 1,3 and 6: 'the state authority is God's servant working for your own good'.

In Calvin's understanding of Romans 13, it is not the nation that gives the state authority its mandate, but God who called it into being. On the basis of his own experience and of God's dealings with ancient Israel, Calvin does indeed make a case for aristocracy modified by popular government in his Institutes (1962:II, 657). Although this would include elections, this does not mean that the mandate of the state authority is regarded as deriving from the democratic majority. Calvin was merely looking 
around for a form of government that would, in the European context of his time, serve as the means to meet God's requirements for the authorities, set out inter alia in Romans 13. In their task of satisfying God's demands, the authorities are answerable to God and the citizenry.

In the light of Romans 13, Calvin understands the state authorities as 'God's servant for your own good' to mean that the magistrates must be concerned for the general welfare of men (verse 1, 1947:479) or of the subjects or 'the public' (verse 4, 1947: 481 ); promoting the peace of the good and curbing the excesses of the evil (with reference to verse 3, where the ruler praises those who do good, 1947:480; cf Calvin 1962: II, 654 and Calvin's commentary on 1 Pt 2:14, 1948:82). Elsewhere Calvin supplements this perspective, saying that the authorities are called by God to protect and promote civil order and true religion (1962:II, 653; cf Nauta s a:41); that in the process of doing so they serve God's righteousness in the execution of civil righteousness; that they act as vice-regents of God (1962:II, 658); and that their legislation ought to meet the rule of love, 'all' righteousness, humanity, benevolence and reasonableness. These principles, Calvin believed, were implanted by God in nature and the human heart (1962:II, 6644). As a servant of God, the state authority must give effect to both the first and second tables of the law (1962:II, 655-656), thus ensuring that only the true God is worshipped.

Briefly summarised, according to Calvin, the state which moves on the "public terrain' must pursue right and righteousness in the interest of all or for the benefit of all (cf Schippers 1959:141). This is its divine commission. Therefore Calvin also speaks of a Christian society (1962, II, 665), and holds that the vindication of right and righteousness should be the sole objective of the complainant and the accused in judicial proceedings (1962:II, 666). Magistrates must be pastors of their people, vindicators of innocence and guardians of righteousness (1962:II, 670; Schippers 1959:140). And precisely because the ruler is a servant of God, he has no alternative but to use public means to promote true religion. A servant working for the good of all ...

Interestingly enough, there is sharp difference of opinion as to whether or not Calvin's vision of society can be termed a theocracy. In his well-known work on the church and state in Calvin, Bohatec concludes that theocracy is at the forefront of the Genevan Reformer's thinking, that it is the premise on which he builds (1937:179). Both Abraham Kuyper (s a:215; 1959:68) and his son H H Kuyper (see Douma \& Van der Vegt 1978:60) dispute this. For them the only form of theocracy is God's direct rule of ancient Israel, which has no parallels. It may be sensitivity to Kuyper's view that prompts Nauta to say that in Calvin's case it is probably more appropriate to speak of a bibliocracy (s a:60). 
Both Bohatec and Kuyper acknowledge that Calvin was convinced of the sovereignty of God in church and state and that for him Scriptural pronouncements on civil authority, such as those in Romans 13, were guiding principles. Clearly he could not propagate the form of government that prevailed in Old Testament times in his day. Furthermore the term bibliocracy suggests a misinterpretation of the nature of the message of Scripture, and this would be an injustice to Calvin, who was convinced that the Bible did not say everything on all subjects and that the magistrates should have the freedom to make laws on certain practical matters (s a iii:246).

However, if theocracy means in essence that the sovereignty and government of God are acknowledged in all spheres of life, then Bohatec is right. For Calvin would agree that government by means of magistrates could in different situations also be embodied in various forms of state.

\section{APPLICATION TO SOUTH AFRICA}

By thus defining the task of the civil authorities on the basis of Romans 13, the Genevan Reformer raises a number of issues that are also pertinent in present-day South Africa: the conduct of the authorities in the general juridical interest; the creation of a public order based on law, peace and quiet; the question concerning a Christian or a secular or religiously neutral state.

State conduct in the general juridical interest in the first/third world situation in which South Africa finds itself is fraught with difficulties. Furthermore, applications based on Calvin would necessitate thorough analyses of the theologian and of the current situation. If we add to this that the former assignment must be placed in a Reformed context, the complexity of the task becomes apparent. Both because of limitations of space and because one does not want to annex Calvin to a particular political point of view, a few general remarks are in order.

According to Calvin's understanding of Romans 13, action in the general juridical interest within a framework of peace and quiet (cf his sermon on $1 \mathrm{Tm} 2: 2,1983: 145$ ) necessitates, in the first place, that the authorities and the opposition parties seek the will of God as to what is right. This is hardly a consideration in the democratist climate prevailing in South Africa at the moment. Democracy in some or other guise (Degenaar 1996:9) is virtually the only arbiter in every matter. In this situation, people of Reformed persuasion are unable to convince others that a biblically justified or Christian political dispensation is not inherently discriminatory. How ironical when it is the right derived from God that is objective and stripped of group interest and selfinterest - unlike the tyranny of the majority or unbridled individualism! 
In the words of Nauta, Calvin did not achieve complete clarity regarding the relationship between church and state (s a:44). Yet the logical outcome of his view on the state authority is that its primary responsibility is to execute righteousness and thus to be obedient to God. However, his use of the state apparatus to promote the true faith and to combat heresy is fundamentally at odds with his conviction that the Gospel is brought home by Word and Spirit (s a i:48ff). In addition, he holds that the church, unlike the state, cannot resort to coercion in making the message known (1962:I, 395). A Christian government can acknowledge the living God in its implementation of what is right without privileging a particular denomination or theology. After all, what is at issue is not an ecclesiastical creed but the political confession that right comes from God5.

It is, furthermore, a simple exercise in Biblical realism that the escalation of crime will put paid to the elimination of first/third world differences. Order, peace and quiet are the juridically qualified obverse of human development in all spheres, an ennobling work ethic, job creation, local and foreign economic initiatives, the elimination of poverty and the curbing of lawlessness. Confidence in the law among subjects who must evaluate the authorities in the light of Romans 13 is seriously impaired by the following examples: a Free State daily announces 454 'perfect' (unsolved) murders in 1995 in this poorly populated province (Die Volksblad 31-05-116:1); according to the Nedcor report $45,6 \%$ of South Africans believe that violence and crime are the biggest problem in the country; and the same report claims that, because of crime, $82 \%$ of small businesses in the country are no longer creating job opportunities (Die Volksblad 12-06-1996:3).

In addition, there is a growing cynical-perception among whites that a policy of officially supported affirmative action may be directly related to reverse discrimination and declining standards (Capraro 1996b:7). After all, it targets whites, purely on the grounds of race and not on account of any proven complicity in apartheid.

Even if these statistics and claims are inaccurate, they make perceptions look like realities in the South African state.

\section{THE CIVIL AUTHORITY GOD'S AVENGER OF EVIL}

On the basis of Romans 13:4, 'he beareth not the sword in vain' or 'his power to punish is real', Calvin calls the civil authority God's avenger to punish evil and suppress injustice. God has given the authorities the sword to enable them to fulfil this function (1947:481).

With reference to Romans 12:19, 'Never take revenge, my friends, but instead let God's anger do it', and Romans 13:4, Calvin connects the civil authority as avenger to 
punish evil with God's judgement. It is not for the individual to take vengeance or visit retribution; the magistrates as instruments in God's hands must see that justice is done. Therefore plaintiffs must not try to misuse the magistrates for their own vengeful purposes. Plaintiffs and magistrates alike should be solely motivated by justice, without any thought of returning evil for evil (1962:II, 666-667).

Aided by the power of the sword, the authorities must pursue righteousness at home and abroad. In this regard, Calvin puts forward a strong case on Biblical grounds for a defensive war. However, all avenues for peace must first be explored and the authorities must, in this matter too, be led by a strong sense of the general good (1962:II, 661-662; cf Van Wyk 1984:19).

Calvin might just as well have had the South African situation in mind when he concluded his commentary on Romans 13:4 with a reference to capital punishment. For him the use of this sanction is no more than the authorities' obedience to God's command (1947:481-482; cf Van Wyk 1948:19). Sharply - and to us in South Africa - pertinently, he condemns an authority that sheathes the sword 'while nefarious men wade through murder and slaughter'. He concedes that excessive use of the power of the sword may wound rather than cure. But, he continues, a superstitious (ideological) pursuit of clemency falls into cruel inhumanity when it gives way to soft indulgence, to the destruction of many (1962:II, 661).

There may be a country which, if murder were not visited with fearful punishments, would instantly become a prey to robbery and slaughter. There may be an age requiring that the severity of punishments should be increased (1962:II, 665).

How appropriate the 'country' and the 'age' are to our circumstances!

Apart from the fact that punishment meted out by the civil authorities must suppress evil and injustice and maintain law and order (Calvin 1947:479), Calvin also considers it necessary for 'wicked and pestilential' men who act against the public interest (1962:II, 667). The high incidence of corruption, the waste of money and the proverbial gravy train, which have become characteristic of the South African financial management, would fall under this heading. Indeed Calvin regarded the squandering of public funds as an unscriptural evil. In his view state expenditure should be responsibly weighed to ensure that it serves public need or the general interest (1962:II, 662-663).

\section{GOVERNMENTS OF INJUSTICE AND RESISTANCE}

In his commentary on Romans 13 , verses $1,3 \& 5$, Calvin admits that there may be governments that exercise their authority illegitimately. However, they remain officebearers of God with a divine right to rule. Therefore they must also be honoured and obeyed, for they serve as God's scourge to punish the people's sin (1947:479-482). 
The first reaction of a believing subject to an unjust and 'impious and sacrilegious' ruler must therefore be humility before God on account of his own sin. This humility also helps to cultivate endurance in the face of injustice. Furthermore, in this situation the believer must call on the Lord for help, for it is not in man's power to rescue himself from such a disaster (1962:II, 670-671, 673-674).

On the matter of resistance, in his commentary on Romans 13 Calvin expresses himself unambiguously on one point: no 'private individual' may usurp the authority of those appointed over us by God (1947:482). Although this matter receives more explicit attention in his letters, we shall confine ourselves to the commentary and to his Institutes as the compendium of his views on doctrine and life. In the latter work Calvin devotes only two further paragraphs to this matter.

According to Calvin, submissiveness in the face of the 'undue license' of rulers is not necessarily the responsible role of a citizen. He can speak against it, bring his prophetic witness against it. But this is not the issue.

Further or alternative forms of resistance designed to abrogate the caprice of rulers and the lawfully binding consequences of their actions must come from the authority sector: from the so-called popular magistrates. Like the Ephori who opposed the Spartan kings and the tribunes who opposed the Roman consuls, these officials are part of the authority structure. By the ordinance of God they are obliged to guard the liberty and right of the people. If they fail in this, it is a criminal betrayal of their trust (1962:II, 675).

Doumergue understands Calvin to be saying that the right to resist may be exercised by rulers, city authorities and ministers, but not by individuals (s a:144-145). Nauta quite rightly points out that Calvin has remarkably little to say on this score. However, what is clear is that the right of resistance may not be regarded as a natural right of the citizenry but is linked with public right (s a:76-77).

Seen in context, Calvin regards resistance, in the sense of the abrogation of certain measures taken by the authorities, as a sort of last resort. The fact that he accords the right of resistance to the lower magistrates is clearly tied up with the authority structure of the time. It is therefore situation-bound and not necessarily of universal validity. One must also note that Calvin's attitude was probably also influenced by a fear, natural in his day, that a populist government carried the risk of unrest and chaos (1962:II, 656). The underlying universally valid principle may probably be regarded as the maintenance of the general good in the sphere of public order: a consideration to which Calvin also gave great weight in discussing the taking up of the sword by the authorities (1962:II, 661-662).

Applied to the South African situation, the following principles may lead people of Reformed faith to responsible action. Resistance, whether in the form of civil disobedience or of violent resistance, may be exercised only as a very last resort. Further, 
there must be reasonable certainty that such action would serve the general good and would be in the interest of public law (cf Du Plessis 1977:71).

\section{CONCLUSION}

In truly Reformed manner it would be possible to enter into dialogue with Calvin on some of his conclusions drawn from Romans 13:1-7: his emphasis on the public order which allows little scope for the rehabilitation of the offender as part of the restitution process; some consequences of his definition of the civil authority's task as servant of God; and his almost cursory and incomplete treatment of the question of a right to resistance in his exposition of Romans 13. A bonus in his commentary on this pericope is his direct, simple and lucid formulation of key principles which, in view of their Biblical grounding, are valid for South Africa too. This state of affairs affords us considerable homiletic material for our situation and explains why Calvin has remained pertinent for so long and in so many situations.

\section{End Notes}

1 cf the subtitle of Scholtemeijer's (1973) biography of Calvin: 'Die stryder vir die eer van God'.

2 Quoting Runia, Simpson (1984:v) characterises Calvin as, in summary, 'the man of the one book'. Of course, this is not literally so. However, viewed in the context of Calvin's life, the Institutes is the compendium of his convictions in respect of doctrine and life. The growth of Institutes from 1536 to 1559 also reflects aspects of his spiritual development and his struggle against certain trends. In this sense, therefore, it even has an autobiographical aspect (cf Smipson 1984:xii).

3 Simpson (1984:viii) quotes Torrance with approval to the effect that Calvin is the father of modern theology and Scriptual exegesis.

4 On this matter he shows remarkable correspondence with Luther; cf Hoek (1982:288), casting doubt on his doctrine of the radical depravity of man, cf Calvin ( $\mathrm{s}$ a [i]:245ff).

5 Calvin's view of the task of the church and state in society was a sort of embryonic stage of the later development in Reformed Protestantism which accorded church and state each its distinguishable vocation and commission, Nauta (s a:53): Hence Calvin's need for a Scriptural church order which gave the church a free hand to order its affairs and his convictions that the authorities should be called in only if it was necessary to call the unwilling to book, Praamsma (s a:121).

6 This Van Wyk (1984:20) interprets as hesitancy to discuss the matter. 


\section{Works Consulted}

Berkhof, L 1947. Introduction, in Calvin, J, Commentaries on the Epistle of Paul the apostle to the Romans. Grand Rapids: Eerdmans.

Beza, T 1984. 'n Noukeurige lewensbeskrywing van Calvyn, vertaal deur H W Simpson in Calvyn, Johannes, 1559. Institusie van die Christelike Godsdiens I, Potchefstroom: Calvyn Jubileum Boekefonds.

Bohatec, J 1937. Calvins Lehre von Staat und Kirche. Breslau: Marcus.

Capraro, I 1996a. 'n Perspektief vanaf die buiteland. Die Volksblad, 14 Junie 1996.

- 1996b. Talle Afrikaanses wil na Brittanje uitwyk. Die Volksblad, 17 Junie 1996.

Calvin, J 1947. Commentaries on the epistle of Paul the apostle to the Romans. J Owen's tr of Calvin's commentary 'composed at Strasburg in the year 1539'. Grand Rapids: Eerdmans.

- 1948. Commentaries on the catholic epistles, tr by J Owen. Grand Rapids: Eerdmans.

- 1950. Uitlegging van de zendbrief van Paulus aan de Romeinen, Opnieuw vertaald uit het Latijn naar de uitgave van Baum, Cunitz en Reuss (1892) door D J de Groot. Amsterdam: Bottenburg.

- 1962. Institutes of the Christian Religion, tr by H Beveridge; 1962 reprint in two vols. London: James Clarke.

- 1983. Sermons on Timothy and Titus (Facsimile of 1579 edition). Edinburgh: Banner of Truth.

Degenaar, J 1996 Red demokrasie in SA van Jakobyne en populiste. Die Volksblad. De Jong, O 1987 Geschiedenis der kerk. 11e druk. Nijkerk: Callenbach.

Die Volksblad: various issues.

Douma, J \& Van der Vegt, W H 1978. Het gepredikte Woord. Franeker: T Wever.

Doumergue, E n d. Calvyn als mensch en hervormer. Amsterdam: Ten Have.

Du Plessis, L M 1977. Calvyn oor die staat en die reg. 2e druk. Potchefstroom: PU vir CHO.

Groen van Prinsterer, G s a. Ongeloof en revolutie. 3e druk. Amsterdam: Bottenburg.

Hexham, I 1981. The irony of apartheid: The struggle for national independence of Afrikaner Calvinism against British Imperialism. New York: Edwin Mellen.

Hoek, J 1982. Luthers twee-rijken-leer, in Balke, W et al, Luther en het gereformeerd protestantisme. Den Haag: Boekencentrum, 283-306.

Nederduitse Gereformeerde Kerk, 1990. Kerk en samelewing. Bloemfontein: Pro Christo.

Kuyper, A s a. De Gemeene Gratie, III. 4e druk. Kampen: Kok. 
Kuyper, A 1959. Het Calvinisme. 3e druk. Kampen: Kok.

Nauta, D n.d. Calvijn en de Staatkunde. Den Haag: Anti-Revolutionaire Partijstichting.

Ntoane, L R L 1983. A cry for life. Kampen: Kok.

Owen, J 1947. Translator's preface, in Calvin, J, Commentaries on the epistle of Paul the apostle to the Romans. Grand Rapids: Eerdmans, v-xix.

Praamsma, L s a. Calvijn. Wageningen: Zomer \& Keunings.

Schippers, R 1959. Johannes Calvijn. Kampen: Kok.

Simpson, H W. Voorwoord, in Calvyn, Johannes, 1559, Institusie van die Christelike Godsdiens, I. Potchefstroom: Calvyn Jubileum Boekefonds.

Stoker, H G s a. Die stryd om die ordes. Pretoria: Caxton.

Strauss, P J 1992. Kerk, staat en politieke modelle in 'Kerk en samelewing - 1990'. HTS 48/3 \& 4, 943-956.

Van Niekerk, A 1987. Staatsgesag en burgerlike ongehoorsaamheid, in Du Toit, D A, Staatsgesag en burgerlike ongehoorsaamheid. Kaapstad: Lux Verbi.

Van Wyk, J H 1984. Calvyn oor die Christelike lewe. Pretoria: NG Kerkboekhandel. 